\title{
Changing Systems of Social Protection in the Context of the Changing Political Economies since the 1980s
}

\author{
Mudanças nos Sistemas de Proteção Social no Contexto \\ de Transformações das Economias Políticas desde os anos 1980
}

Evelyne Huber ${ }^{1}$

Sara Niedzwiecki ${ }^{2}$
${ }^{1}$ Departament of Political Science, University of North Carolina. Campus Box 3265 Chapel Hill NC EUA. ehuber@ad.unc.edu

${ }^{2}$ Politics Department, University, University of California. Santa Cruz CA EUA.

\begin{abstract}
This article provides an overview of the profound changes in the more advanced welfare states in Europe and Latin America over the past 35 years. Deindustrialization, informalization, and the rise of unstable employment, combined with aging populations rendered traditional employment-based models of social protection less effective and at the same time increased demands on the welfare state. The two main responses to these challenges were efforts at cost containment and inclusion in non-contributory social protection schemes and health services of those in marginal labor market positions. The mix of these two responses and the depth of the changes were shaped by the intensity of the economic and demographic pressures, policy legacies, the partisan preferences of governing parties and coalitional constraints, the strength of groups in civil society, the presence of veto points in the political system, and in Latin America the process of democratization, along with the international context. A broad comparison between Latin America and Europe highlights the importance of the international context in the form of a relentless pursuit of neoliberal models by the International Financial Institutions in Latin America in contrast to the model of Social Europe promoted by the European Union.
\end{abstract}

Key words Europe, Latin America, Social policies, Democracy
Resumo $O$ artigo apresenta um panorama das profundas mudanças nos Estados de Bem-Estar Social mais avançados da Europa e da América Latina nos últimos 35 anos. Desindustrialização, informalização e o aumento dos empregos instáveis, associados ao envelhecimento populacional, tornaram os modelos de proteção social baseados no emprego menos efetivos e, ao mesmo tempo, aumentaram as pressões sobre os Estados de Bem-Estar Social. As principais respostas para esses desafios foram esforços de contenção de custos e de inclusão em esquemas de proteção social e de saúde não contributivos das pessoas em posições precárias nos mercados de trabalho. A combinação dessas respostas e a profundidade das mudanças foram moldadas pela intensidade das pressões econômicas e demográficas, legados das politicas, preferências dos partidos no governo e constrangimentos pelas coalizões de poder, força dos grupos da sociedade civil, presença de pontos de veto no sistema político e, na América Latina, o processo de democratização e o contexto internacional. A comparação entre América Latina e Europa destaca a importância do contexto internacional expressa em pressões das instituições financeiras internacionais pela adoção de modelos neoliberais na América Latina, em contraste com o modelo de Europa Social promovido pela União Europeia.

Palavras-chave Europa, América Latina, Politicas sociais, Democracia 


\section{Introduction}

Welfare states around the world have undergone profound changes since the 1980s. Advanced welfare states in Europe, North America, and South America have been reformed in various ways and many previously minimalist welfare states in other areas, particularly in Asia, have been expanded. Our focus here will be on changes in the most developed welfare states in Europe and Latin America.

Profound changes in these countries were a response to growing economic and demographic pressures. The slowing of economic growth and the rising levels of unemployment in advanced industrial countries endangered the financial viability of generous welfare states, and the debt crisis in Latin America generated intense pressures for reduction of all kinds of social expenditures. Countries in both areas suffered deindustrialization as a result of economic globalization and technological change, which led to the growth of low-paid and unstable employment in advanced industrial countries and to growing informalization in Latin America. Both of these developments rendered traditional employment-based models of social protection less effective. Finally, both sets of countries have seen a growth in the aged population and thus higher demand on pension and health care systems. And the advanced industrial countries have seen an increase in single mother households, a group highly vulnerable to poverty and thus dependent on the welfare state.

The general response to these pressures has been two-fold: strong efforts at cost-containment on the one hand, and inclusion in social protection of those excluded from contributory social insurance because of their marginal labor market status on the other hand. However, the mix of these two responses and the timing and depth of the changes have varied greatly between countries. In the period of welfare state construction, the key variables shaping the welfare state in advanced industrial countries were partisan government, that is, the strength of left, Christian Democratic, and secular right parties; the strength of organized labor; and the number of veto points in the constitutional structure ${ }^{1}$. In the case of Latin America, the existence of democratic periods and the strength of left parties on the one hand, and the strength of labor on the other hand were important factors ${ }^{2}$. In the period since the 1980s, in both sets of countries, factors in addition to democracy, the partisan preferences of the governing parties and constitutional veto points have assumed importance in shaping the differences in adaptations, namely the intensity of the economic and demographic pressures, policy legacies, coalitional pressures, and the international context. Nevertheless, partisan preferences and the distribution of political power continue to matter a great deal.

If one looks at policy proposals of political parties and of governments with different partisan composition, one can delineate quite consistent partisan differences between left and right. The left consistently favors more redistributive and solidaristic policy designs, which require a strong state role as payer, provider, and regulator. The right consistently favors closer links between contributions and benefits and a lowering of commitments and expenditures in public programs, which opens the way for private payers and providers and for more reliance on the market. When it comes to financing, the left prefers to rely on public transfers and services whereas the right prefers to rely on tax incentives and private services. These preferences are clearly visible in proposals for pension reforms and health care reforms.

We can find similar differences in policy preferences regarding unemployment compensation and positive and negative labor activation, that is, efforts to integrate people into the labor force with inducements or punishment. Proposals from the right prioritize negative activation - cutting replacement rates in unemployment insurance and reducing the duration of benefits, whereas preferences from the left prioritize inclusion of non-traditional workers and positive activation - emphasis on training and job placement. During deep and lasting economic downturns, when employment creation becomes necessary, the left prefers to create public sector jobs and the right prefers to subsidize low wage work in the private sector.

Such policy preferences and proposals are rarely fully reflected in policy. Only in situations of one-party majority government in parliamentary systems without veto points might one even expect them to be. Yet, even in these situations, policy legacies shape reform options. Cutbacks in public transfers and services are easier where they are less universalistic to begin with. Redistribution to serve previously excluded groups is more difficult where private providers play important roles. Moreover, parties are likely to encounter resistance against radical measures and end up with policy packages that are multi-dimension- 
al and offer some compensation to some groups that are negatively affected. In coalition governments and systems with veto points the reliance on complex policy packages is particularly pronounced ${ }^{3}$. Moreover, at times governing parties in countries with a tradition of involvement of unions and employers in social policy making sought a compromise with the opposition and the social partners, in the interest of devising viable long-term solutions for major reforms.

In Latin America, problem pressures were also important. In countries with fully matured and generous pension systems, pressures for privatization were particularly strong ${ }^{4}$. Moreover, the depth of the debt crisis shaped the intensity of the search for cost controls. However, policy legacies and political alignments were important as well. Pinochet's Chile is the one case where policy preferences of the ruling elite were fully reflected in social policy reforms, with total privatization of pensions and great expansion of the role of the private sector in health and education. In cases where significant social policy reforms were put on the table by democratic governments, such as in Argentina, Uruguay, and Brazil, we see a similar picture of mixed packages as in advanced industrial countries. However, we also see clear differences in partisan preferences. Left governments preferred and actively pursued more expansionary and universalistic social policies that assigned a larger role to the state than right-leaning governments. Nevertheless, policy legacies began to constrain governments of the right as well. For instance, right-wing President Sebastián Piñera in Chile had to promise during the election campaign that he would keep intact some of the social policies implemented by the Concertación governments, and he did so when in office ${ }^{5}$.

Power relations in the international system had an important impact on the directions of social policy reforms. In Latin America, the pressures from International Financial Institutions (IFIs) for neoliberal reforms in the economy and in social policy were intense, and large countries like Brazil were in a better position to resist these pressures than small countries like Bolivia. A broad comparison between Latin America and Europe makes clear just how important the international context was for the type of social policy reforms implemented. In Latin America, the relentless pursuit of neoliberal models by the IFIs put pension privatization on the agenda everywhere, and many countries adopted full or partial privatization, whereas not a single European country privatized a large part of its pension system. The model of Social Europe, promoted by the European Union, emphasized inclusion of all sectors into the system of social protection.

Given the space constraints of this article, we cannot provide the empirical material to support our arguments. After publication of this journal issue we shall post a longer version of this article with empirical analyses at http://huberandstephens.web.unc.edu/evelyne-huber/chapters/.

\section{Welfare State Reforms in Advanced Industrial Countries}

As noted, under the economic and demographic pressures beginning in the 1970s and intensifying in the 1980s, cost containment and activation policies became the governing principles of welfare state policy. In the early 1980s, most countries still increased the generosity of unemployment replacement rates and the Continental European countries resorted to early retirements and disability programs to deal with the rising unemployment levels, but by the end of the decade it became clear that these policies were not fiscally sustainable. By the 1990s social policy reform took hold everywhere.

There were two ideologically driven exceptions to this pattern of problem driven adjustments. In Britain, Margaret Thatcher started her attack on the welfare state right after coming to power in 1979, and in the United States Ronald Reagan used the deficits he had created by lowering taxes as an excuse to cut the welfare state. In the other advanced countries, the responses to slower growth, rising unemployment and consequent fiscal difficulties were two-fold. First, efforts to control expenditures consisted of a lowering of replacement rates in unemployment and sick pay insurance, changes in pension systems, and increasing reliance on out-of-pocket expenses and cost controls in the health care system. Second, efforts to increase labor force participation rates consisted of activation requirements for recipients of unemployment benefits, job training and placement, and work/ family reconciliation policies. Work/ family reconciliation policies include promotion of part-time work with labor rights and benefits, provision of free or subsidized child care, and provisions for paid parental leave. This is the only area of the welfare state where actual expansion has taken place over the past two decades.

In analyzing changes in the welfare state since the 1980s, using welfare state regimes as an an- 
alytical category remains a useful tool, because reformers in the different regimes confronted very different policy legacies. The Nordic countries developed their welfare states mainly under governments dominated by social democratic parties, and by the mid-1980s they were highly generous, highly redistributive, offering a large variety of publicly financed and provided social services, and having a universalistic orientation, combining citizenship-based with employment-based programs. The Continental countries had all Bismarckian, that is, employment-based welfare states. In most of them, Christian democratic parties exercised strong influence, often in competition with social democratic parties. They were also highly generous but less redistributive than the Nordic regimes, taking a particularistic, group-based rather than universalistic approach. They did not offer many social services, relying on the family and religious institutions instead; to the extent that social services were publicly funded, they were mostly privately provided. The Anglo-Saxon or liberal welfare states had a residual character, covering mainly those unable to cover themselves with market-based solutions or being insured through their employment, being neither generous nor very redistributive, and offering few services. The big exception to this pattern of course is the British national health service, a program that was implemented by the post-WWII Labour government and became highly popular and thus resistant to cuts by Conservative governments.

As noted, one of the most immediate pressures on the welfare state was the rising level of unemployment, and accordingly unemployment replacement rates became a focus of cost-cutting measures. Sweden and Denmark had the highest unemployment replacement rates, over $90 \%$ of earnings for a worker with average income, but after 2000 these rates had been reduced in all the Nordic countries to between 60 and 80\%. Replacement rates in the Continental countries had reached roughly that same level, $60-80 \%$, by the mid-1980s, and they stayed stable after that. The liberal welfare state regimes started off with lower replacement rates and these rates fell further, most steeply in the UK, Ireland, and New Zealand, where they fell to between 35 and $45 \%$.

The replacement rates indicated are for a worker with average income. Thus, they do not reveal changes in the replacement rate across income categories. Clasen and $\mathrm{Clegg}^{6}$ argue that unemployment compensation underwent a process of homogenization of benefits and of programs. Specifically, several countries lowered ceilings for unemployment benefits, reduced the link to previous earnings, and weakened or abolished the distinction between unemployment insurance and means-tested social assistance. Thus, the replacement rates for higher income groups fell more steeply than the figures above suggest.

The Continental countries that had used disability pensions to reduce the labor force and support older unemployed workers tightened eligibility conditions for these schemes and attempted to reintegrate some of these workers into physically less demanding jobs. These efforts were part of the general emphasis on activation, which entailed a combination of positive and negative incentives. The negative incentives were shortened duration of regular unemployment insurance benefits and thus faster transition into programs with lower unemployment assistance or social assistance benefits. In order to receive benefits, recipients were required to participate in training, look for a job, and accept a job even if the recipient was overqualified or the job had a lower wage than the job that had been lost.

Cost containment was the key behind pension reforms. Beginning in the 1980s, all the fully matured PAYGO pension systems came under pressure from of a combination of aging populations, slower wage growth, and declining standard employment ${ }^{7}$. Aging populations and slower wage growth meant that the revenue growth of the pension funds would not keep pace in the future with the growth in pension expenditures. Declining standard employment meant that fewer people would accumulate sufficient pension credits for a regular pension. This called for the introduction or improvement of minimum pensions, or social assistance pensions.

Every single advanced industrial country undertook some kind of pension reform. The most common reforms concerned the formula for calculating benefits and the qualifying conditions. Governments lengthened the base years for calculating the replacement rate and switched from indexation to wage growth to indexation to inflation. They lengthened the contribution period for pension entitlements, raised the retirement age, and tightened penalties for early retirement. More far-reaching changes entailed a switch from defined benefit to defined contribution systems, and the introduction of demographic factors into the calculation of the benefits. Structural changes brought introduction of supplementary second and third pillars in the form of collective occupational and individual private schemes, in 
some countries mandatory and in others collectively negotiated or voluntary, but supported through the tax system. A further common trend was towards bringing privileges of public sector employees in line with the lower benefits of private sector employees.

Clearly, pension reforms have been politically very difficult to implement. Of all the social programs other than health care they have the widest coverage and impact. The difficulty has been aggravated where trade unions have played roles in the administration of pension funds. As a result, successful reformers tended to rely on two main strategies: First, they phased in reforms over a long time period. Second, they proceeded in a step-wise fashion rather than proposing sweeping overhauls.

The purpose of phasing in reforms over a long period was to neutralize opposition from the people who would be most likely to engage in major protest actions - those relatively close to retirement. People under 40 years of age tend not to think a lot about retirement. Raising the retirement age and benefits over 25 years will only affect people 40 years of age and younger - a constituency for whom the issue is not (yet) highly salient. Indeed, the time lag between the year of the major pension reforms and their projected full implementation in Germany ranges from 23 to approximately 26 years, and in Italy it is a full 40 years $^{8}$.

Health care costs have been escalating across OECD countries, driven primarily by advances in medical technology but also by the rising aged proportion of the population ${ }^{9}$. Since governments foot the major part of the medical bill in every country except the United States, governments have attempted to contain costs. In classifying public health care systems, one can distinguish between National Health Services (NHS) as in the Nordic countries, the UK and New Zealand; National Health Insurance (NHI) with a single government payer as in Canada; decentralized National Health Insurances as in Continental Europe and Australia; and mixed public and private health insurance systems as in the US and Switzerland. Hacker ${ }^{9}$ argues that governments with NHSs in countries with veto free constitutional structures (which is the case for the Nordic countries, the UK and New Zealand) are in the best position to control costs. Britain is a prime example: Conservative governments starved the NHS of funds and New Labour greatly increased expenditures for the system.

The figures for public percent of total health care spending suggest no diminution of govern- ments' role in health care. However, the spending figures hide a rise in private provision of health care in many countries and/or an introduction of competition in health care provision in which public providers compete with private provid$\mathrm{ers}^{10}$. For example, if a government introduces a voucher system in which the citizen can choose between a public or private provider, the government share of total health care spending may stay the same while private provision of health services increases. In her study of markets in the provision of health care, education, and long term care, Gingrich ${ }^{10}$ cautions that this trend cannot be seen as an unambiguous victory for neo-liberal preferences over traditional social preferences for state provision. Rather different types of markets have quite different distributive implications and thus should map onto the traditional policy preferences of the left and right.

Looking at the whole period since 1990, with the exception of Southern Europe where countries were attempting to catch up to the rest of Europe, the picture is one of general stability in the share of GDP devoted to social expenditures at the beginning and the end of the period, as well as in the relative generosity of the three worlds. The Nordic countries and France, Germany, Belgium, and Austria remain the highest spenders and the countries with the liberal regimes the lowest spenders. To the extent there has been change, it has trended upwards, most noticeably in the Mediterranean world, but also in the UK and Australia, and more slightly in most Continental and liberal regimes. The only countries that clearly lowered their social spending effort and moved from being among the highest to the lowest of their respective worlds are the Netherlands and Ireland. However, the key is that the labor market and demographic transformations discussed above significantly increased the problem load on the welfare state, so the welfare state at the end of the first decade of the $21^{\text {st }}$ century was doing more things with the same share of GDP as 20-30 years earlier. In order to be able to serve more clients and cope with the greater problem load by introducing new kinds of programs, the social rights under the old programs had to be reformed, which is where the political struggles unfolded.

\section{Reforms in Latin America's Social Protection Systems}

The most advanced Latin American welfare states are those in Argentina, Brazil, Costa Rica, 
Chile, and Uruguay. Even there, coverage through the contributory social security system was never even close to universal. The debt crisis of the 1980s further reduced the portion of the labor force in the formal sector and thus with social security coverage, and it also greatly intensified financial pressures within the matured systems. Moreover, it greatly increased the leverage of IFIs, such that - in contrast to Europe - the pressures in the first phase of reforms went uniformly in a neoliberal direction. Only after 2000, with greater economic room for maneuver and more consolidated democratic institutions was a clear change in orientation possible, driven by the consolidation of democracy and partisan preferences of political parties and executives. Just like in the advanced industrial countries, partisan preferences could not necessarily be translated fully into policies because of veto points, coalitional pressures, and policy legacies.

Social protection systems in Latin America first emerged around the 1940s in the context of Import Substitution Industrialization (ISI). The early introduction of social protection systems in Argentina, Brazil, Chile, Uruguay, and Costa Rica, the pioneering countries was a response to pressures from middle and working classes ${ }^{11}$, either in contexts of longer democratic histories or in contexts where more authoritarian leaders made attempts at labor incorporation. While Uruguay, Costa Rica, and Chile followed a democratic competitive path that exhibited the influence of center-left parties in the formation periods, Brazil and Argentina followed a cooptation of labor path led by Vargas' and Peron's regimes, respectively ${ }^{12}$. These Latin American systems of social protection resembled the Continental European Bismarckian type of welfare state, built on occupationally based insurance, which left large sectors of the population, such as informal and rural workers, excluded. They also proved to be financially unsustainable and were moving towards bankruptcy even before the debt crisis ${ }^{13}$.

As a remedy to the balance of payments and fiscal crises of the Latin American states in the 1980s, IFIs such as the International Monetary Fund, the World Bank, and the Inter-American Development Bank prescribed austerity and structural adjustment programs. According to their diagnosis, the ISI strategy had been too heavily dependent on foreign loans and the state had been too intrusive in the economy. Their solution was therefore to reduce government expenditure, privatize state enterprises, deregulate the economy, and liberalize trade and financial markets. These recommendations influenced Latin American economic policies heavily through the conditionality of funds and through networks of experts with shared educational backgrounds in the IFIs and national governments ${ }^{14}$. Neoliberal reforms of the economy aggravated some of the problems that they were supposed to solve. They produced a net loss in industrial jobs and enlarged the informal sector. As a consequence, tax payments in general and contributions to the social security system in particular decreased.

The crisis of social security systems that incentivized the neoliberal turn in social policy was particularly acute in the pioneering systems of Chile, Uruguay, Argentina, and Brazil. These pension systems suffered a declining ratio of workers to pensioners and, with the increase in the levels of informality and low levels of contributions, increasing deficits ${ }^{4}$. At the same time, pressures for the defense of social protection were feeble because the left and labor movements had been weakened after decades of authoritarian regimes and were further being weakened by the neoliberal reforms.

The 1980s and 1990s were therefore decades of overall retrenchment and neoliberal reform of social assistance, pensions, health and education. Non-contributory social assistance was narrowly targeted to the extremely poor, social security was fully or partially privatized, and health care and education increased the participation of private providers. The paradigm of the pension reforms was the clearest, and nine Latin American countries changed their pension systems from 1981 to 2001. Some (Chile, Bolivia, Mexico, and El Salvador) fully privatized the pension scheme, others (Peru and Colombia) chose private systems parallel to the public system, and still others (Argentina, Uruguay, and Costa Rica) developed mixed systems, with a private component that supplemented the public scheme. Conversely, the blueprint for health reforms was not as straightforward as that of the pension reform, and the number of stakeholders was higher in this sector. Therefore, the reforms tended to be more partial. A similar case was that of education reforms, where policymakers tended towards territorial decentralization of responsibilities and not necessarily state retrenchment.

The implementation of these social policy prescriptions varied widely among cases, shaped by policy legacies from the ISI period and the balance of forces between supporters and opponents of the reforms. The balance of forces 
in turn was shaped by the relative timing of democratization and economic and social policy reforms. The cases of Chile and Brazil illustrate these differences clearly. Chile's extreme orthodox reforms were in part possible because they were carried out under a dictatorship. Pinochet strengthened private providers at the expense of the public sector in in both the health and pension systems. He fully privatized the pension system and created a system of private health insurance and health care providers, the ISAPRES, to which employees could direct their compulsory health care contributions. In contrast, union pressures and lack of party discipline in Congress hindered Brazil's democratic presidents from enacting the wide reforms in social policy that the IFIs preferred. Pension reform was very slow and partial - in fact, it fell short of not only neoliberal designs but also of progressive aspirations for curtailment of high benefits for privileged sectors $^{15}$. Countries that suffered drastic neoliberal economic reforms were poorer performers on a number of socio-economic areas than countries that liberalized more slowly ${ }^{16}$. In general, neoliberal shock treatments left higher levels of poverty and inequality.

The tensions created by market-oriented reforms, in combination with center-left presidents and the consolidation of democracy in the region, prompted reforms towards universalism. The length of time since democratization was crucial in two respects. First, it had allowed for organizations representing the interests of the underprivileged and for left parties to grow in strength. In particular, left parties were able to win subnational elections and prove that they could govern and thus expand their support base. Second, the threat of renewed military intervention receded with time (this was particularly important in Chile), which enabled presidents and cabinets to devote more attention to social policy than to consolidating democracy.

The left-of-center parties that gained executive power after 2000 were helped by the commodity export boom, which allowed them to increase their leverage vis-á-vis IFIs and expand the welfare state. The implementation of more universalistic social policies, together with expanding employment, a decrease in the skill premium due to expansion of education in the previous decade, and increases in the minimum wage, contributed to the decrease in overall levels of poverty and inequality ${ }^{17}$. The more advanced social protection systems of Uruguay, Brazil, Argentina and Chile made varied degrees of prog- ress toward universalism, and such progress was different depending on the policy legacies, on the characteristics of left-parties and their ties to civil society, on veto points, and on coalitional pressures, similar to dynamics in the European cases.

In Brazil, progress was highly constrained by veto points (particularly bicameralism and federalism) and policy legacies in pensions, health care, and social assistance. The high level of fragmentation in the party system meant that the PT never even got close to a majority of seats in the two chambers of parliament. Federalism meant that centrally decided policies could be unevenly implemented across subnational units ${ }^{18,19}$. In addition, policy legacies were highly unfavorable in pensions, including low coverage of vulnerable groups and resistance of civil service unions to decreasing their benefits and to privatization $^{20}$. Finally, the impeachment and ousting of President Dilma Rousseff in 2016 in the context of a serious political and economic crisis has made retrenchment of previously expanded policies a real possibility ${ }^{5}$.

In Argentina bicameralism, coalitional pressures, and federalism were less of a constraint after the 2001-02 crisis, because the president has enjoyed broad support among the weakened parties, unions, and governors. Néstor and Cristina Kirchner nearly dominated Congress since 2003. More universalistic health reforms have been challenging due to union control over the obras sociales, and the crucial role of unions in the Kirchner's power base. The expansion of social policies during left party dominance has been put to test since 2015, when a coalition of right wing parties won the presidency. The new administration has so far implemented a combination of policy drift, status quo maintenance, and moderate expansion ${ }^{5}$. In 2017 legislative elections, the government increased its share of seats in Congress thus increasing the possibility of significant retrenchment.

In Chile, Presidents Lagos and Bachelet were hampered by all kinds of constraints in their efforts to make social policy more universalistic. The senate with its right-leaning appointed members was an important veto point before the constitutional reforms of 2005. Moreover, Lagos and Bachelet were Socialist presidents governing with the support of a center-left coalition, which meant that coalitional pressures worked against an expansion of the state's role in health and education. Additionally, policy legacies were highly unfavorable in so far as both the private pension fund companies and the ISAPRES were for-profit 
enterprises, well connected to the rest of the business community and the parties of the right and thus politically influential.

The Frente Amplio governments in Uruguay faced the fewest constraints and accordingly made most progress in pushing social policy in a universalistic direction. The governments won majorities in both chambers in the 2004 and 2009 legislative elections, and the country is unitary. Policy legacies in health care were more favorable than in the other three countries in that the private providers operated on a not-for-profit basis and did not form alliances with business, nor were they a source of funds for the unions. Accordingly, they could be brought under a public single payer system. The pension system presented a more difficult policy legacy. The 1989 referendum had firmly anchored benefits, including privileged ones, which left little room for reform. The response of the FA was the introduction of an income tax that made pension income taxable, which was an important redistributive step ${ }^{21}$.

\section{Conclusion}

In the case of advanced industrial countries, we argued that problem pressures have forced welfare state reforms designed to put programs on a fiscally sound basis by controlling costs and raising employment levels in all countries. Yet, these reforms have differed markedly in their inclusiveness and distributive impact. Partisanship has continued to play an important role in shaping policies, despite the weight of policy legacies and problem pressures and the obstacles to translation of partisan preferences into policies presented by veto points and the necessity of coalition formation. In fact, in our earlier work we may well have underestimated the continuing strength of partisan influences ${ }^{1,22}$, in part because we focused on policy output and consequences. With the benefit of hindsight, we can see that in the aftermath of the Nordic economic crisis and of New Labour coming to power in Britain, partisan differences reasserted themselves visibly in the shape of new welfare state policies.

In Latin America, problem pressures in the economy were decisive for a strong reform impetus in the 1980s and 1990s. The dismantling of the ISI model also intensified the crisis of the social security systems and left majorities of the population exposed to risks of poverty without a social safety net. Like in advanced industrial countries, the reforms proceeded unevenly; here the differences were due to differential exposure to IFI pressures and different domestic political constellations. Wide exposure to IFI pressures and/or the presence of dictatorships ideologically committed to neoliberalism resulted in far-reaching retrenchment of the state in social protection and social services. Democratic regimes with veto points and coalition requirements allowed for stronger mobilization of resistance against state retrenchment, and a larger domestic economy strengthened governments' hands against IFI impositions. The differential response to neoliberalism in the 1980s and 1990s then left different policy legacies for reformers after 2000.

As economic pressures gave way to economic expansion after 2000, social problem pressures became prime movers of reform. By the same token, domestic political constellations became decisive for the extent of reforms. The electoral victories of left presidents and parties shaped social policy reform agendas in the direction of universalism. Progress on this path by left governments depended again on their control over the legislature, their dependence on coalition partners, and policy legacies. Actual reforms of existing systems of social protection and social services proved extremely difficult in most cases, particularly where private providers were important, with the result that governments resorted to adding programs to serve the previously excluded groups. Key examples here are non-contributory pensions and conditional cash transfers, as well as the expansion of free basic health care services and the expansion and improvement of public education.

Overall, these reforms have moved Latin America's most advanced social protection systems towards universalism, though to different degrees. A question that remains to be answered is whether these reforms are sustainable, both economically and politically. Politically, broadbased and well-functioning systems have proven resilient against retrenchment ${ }^{1}$. At the same time, these reforms have been put to test through the presence of right wing Presidents in Argentina, Brazil, and Chile. Economically, the keys to sustainability are to develop functioning tax systems that can support these broad social policies and to upgrade the skill levels of the labor force and the value added in economic production. Despite some progress in the area of taxation, much remains to be done. Similarly, the steps that have been taken to invest in education, including preschool education, to improve the quality of the labor force and increase labor force participation, need to be intensified and continued. 
What our analysis has revealed clearly in both advanced industrial and Latin American countries is the importance of the political strength of left parties for the chances of universalistic systems of social protection. In advanced industrial countries, the strength of left parties has been in slow decline because they have not been able to fully make up for the losses in their traditional working class base by attracting new middle class supporters. In Latin America, democratization has opened the space for left parties to grow in strength. Their challenge is a similar one in a different class structure - to build cross-class alliances among formal and informal sector workers and the poor. This is not achieved by good social policy alone, but it also requires attention to the organization-building part of politics.

\section{Collaborations}

E Huber and S Niedzwiecki contributed to the preparation of the manuscript. 


\section{References}

1. Huber E, Stephens JD. Development and Crisis of the Welfare State: Parties and Policies in Global Markets. Chicago: University of Chicago Press; 2001.

2. Huber E, Stephens JD. Democracy and the Left: Social Policy and Inequality in Latin America. Chicago: University of Chicago Press; 2012.

3. Bonoli G, Mach A. Switzerland: Adjustment Politics and Institutional Constraints. In: Scharpf FW, Schmidt VA, editors. Welfare and Work in the Open Economy: Diverse Responses to Common Challenges. Oxford: Oxford University Press; 2000. p. 131-174. Vol. II.

4. Madrid RL. Retiring the State: The Politics of Pension Privatization in Latin America and Beyond. Stanford: Stanford University Press; 2003.

5. Niedzwiecki S, Pribble J. Social Policies and Center-Right Governments in Argentina and Chile. Lat Am Polit Soc 2017; 59(3):72-97.

6. Clasen J, Clegg D. The Transformation of Unemployment Protection in Europe. In: Clasen J, Clegg D, editors. Regulating the risk of unemployment: National Adaptations to Post-industrial Labour Markets in Europe. Oxford: Oxford University Press; 2011. p. 333-345.

7. Myles J, Pierson P. The Comparative Political Economy of Pension Reform. In: Pierson P, editor. The New Politics of the Welfare State. Oxford: Oxford University Press; 2001. p. 305-333.

8. Bonoli G, Palier B. When Past Reforms Open New Opportunities: Comparing Old-Age Reforms in Bismarckian Welfare Systems. In: Palier B, Martin C, editors. Reforming the Bismarckian Welfare Systems. Oxford: Blackwell Pub; 2008. p. 29-39.

9. Hacker JS. Dismantling the Health Care State? Political Institutions, Public Policies and the Comparative Politics of Health Reform. Br J Political Sci 2004; 34(4):693724.

10. Gingrich JR. Making Markets in the Welfare State. Cambridge: Cambridge University Press; 2011.

11. Mesa-Lago C. Changing Social Security in Latin America: Toward Alleviating the Social Costs of Economic Reform. Boulder: Lynne Rienner; 1994.

12. Huber E. Options for Social Policy in Latin America: Neoliberal versus Social Democratic Models. In: Esping-Andersen G, editor. Welfare States in Transition: National Adaptations in Global Economies. London: SAGE; 1996. p. 141-191.

13. Mesa-Lago C. Ascent to Bankruptcy: Financing Social Security in Latin America. Pittsburgh: University of Pittsburgh Press; 1989.
14. Teichman JA. The Politics of Freeing Markets in Latin America: Chile, Argentina, and Mexico. Chapel Hill: University of North Carolina Press; 2001.

15. Niedzwiecki S. The Effect of Unions and Organized Civil Society on Social Policy: Pension and Health Reforms in Argentina and Brazil (1988-2008). Lat Am Polit Soc 2014; 56(4):22-48.

16. Huber E, Solt F. Successes and Failures of Neoliberalism. Lat Am Res Rev 2004; 39(3):150-164.

17. López-Calva LF, Lustig N. Declining Inequality in Latin America: A Decade of Progress? Washington: Brookings Institution Press; 2010.

18. Niedzwiecki S. Social Policies, Attribution of Responsibility, and Political Alignments: A Subnational Analysis of Argentina and Brazil. Comp Political Stud 2016; 49(4):457-498.

19. Niedzwiecki S. Uneven Social Policies: The Politics of Subnational Variation in Latin America. Cambridge: Cambridge University Press; 2018.

20. Brooks SM. Social Protection and the Market in Latin America: The Transformation of Social Security Institutions. Cambridge, New York: Cambridge University Press; 2009.

21. Castiglioni R. Las políticas sociales de la nueva (vieja) izquierda uruguaya. Woodrow Wilson International Center for Scholars, Latin America Program [Internet]; Jun 2010 [cited 2018 Mar 15]; 6. Available from: https://www.wilsoncenter.org/sites/default/files/LAP_ Nueva\%20_Izquierza_Uruguaya.pdf

22. Stephens JD, Huber E, Ray L. The Welfare State in Hard Times. In: Kitschelt H, Lange P, Marks G, Stephens JD, editors. Continuity and Change in Contemporary Capitalism. Cambridge: Cambridge University Press; 1999. p. 164-193.

Artigo apresentado em 15/01/2018

Aprovado em 12/03/2018

Versão final apresentada em 03/04/2018 